\title{
APSA Recognizes Outstanding Accomplishments during Annual Meeting
}

Recognizing outstanding achievements in research, the Association honored 18 members of the profession at the APSA Awards Ceremony held in conjunction with the Annual Meeting in Washington. Hosted by 2000 Program Co-Chairs Ira Katznelson and Helen Milner of Columbia University, the major plenary of the meeting drew nearly 500 attendees. Following the ceremony, 2000 APSA President Robert O.

Keohane delivered his Presidential Address, "Governance in a Partially Globalized World."

The Association honored three others for their major contributions to the profession and our understanding and practice of politics. The Association was pleased to honor Herbert A. Simon of Carnegie Melon University with the John Gaus Award honoring a lifetime of exem-

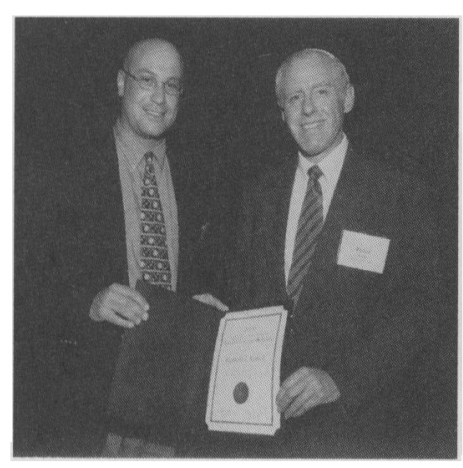

plary scholarship in the joint tradition of political science and public administration.

The award committee wrote that Simon had "revolutionized the study of public administration by showing the fundamental limitation of scholarly arguments based on plausible but untested assumptions and indicating how those assumptions might be put into a more rigorous empirical test." Simon, whose research has ranged from computer science to psychology, administration, economics, and philosophy, was previously awarded the Alfred Nobel Memorial Prize in Economic Sciences in 1978. In addi- tion to receiving the Gaus award, Simon delivered the annual John Gaus lecture, titled "Public Administration in Today's World of Organizations and Markets." The Gaus lecture can be found in this issue of $P S$.

The Carey McWilliams Award, presented annually to an individual who has made a major journalistic contribution to the understanding of politics, was given to Alan Ehrenhalt of Governing magazine. As the long- tention to the sheer hunger for office as a primal animating force in political life, and The Lost City: The Forgotten Virtues of Community in America, which profiles the Chicago of the 1950s.

Eight dissertation prizes were awarded to young scholars who had completed their doctoral studies during 1998 or 1999.

The Gabriel A. Almond Prize for
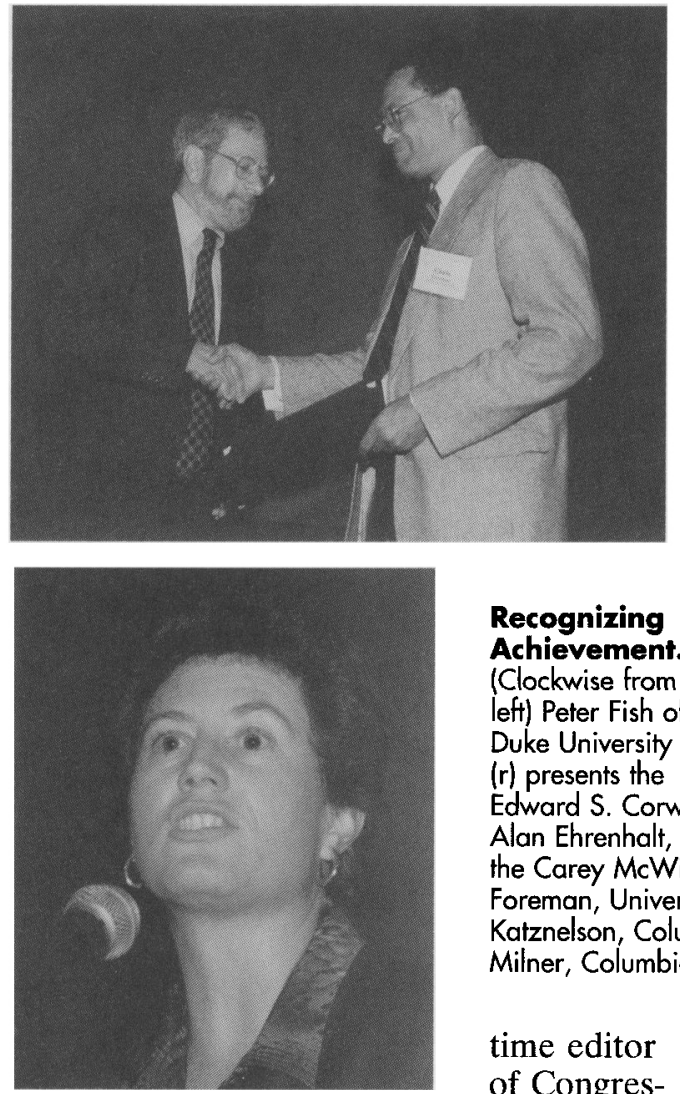

Recognizing Achievement. (Clockwise from left) Peter Fish of Duke University (r) presents the Edward S. Corwin Award to Kenneth I. Kersch of Leigh University; Alan Ehrenhalt, executive editor of Governing magazine (I), accepts the Carey McWilliams prize from committee chair Christopher Foreman, University of Maryland; 2000 Program Co-Chair Ira Katznelson, Columbia University; 2000 Program Co-Chair Helen Milner, Columbia

time editor of Congressional Quarterly's Politics in America, the award committee noted, "Ehrenhalt created a major gateway allowing both scholars and reporters instant access to every individual in the modern Congress and to every electoral constituency shaping it" and that he had done so "with an insight, breadth of knowledge, and attention to important questions that few political journalists can match." Ehrenhalt is also the author of The United State of Ambition: Politicians, Power and the Pursit of Office, which renewed at- the best dissertation in comparative politics was awarded to Anna M. Grzymala-Busse, who is currently at Yale University. Grzymala-Busse completed "Redeeming the Past: The Regeneration of the Communist Successor Parties in East and Central Europe after 1989" under the direction of Gregorz Ekiert at Harvard University.

The 2000 William Anderson Award for the best doctoral dissertation completed and accepted in 1999 or 2000 in the general field of federalism or intergovernmental relations or state and local politics was awarded to Pamela W. Winston of Johns Hopkins University. Winston 
completed her dissertation, "The Devil in Devolution: Welfare, the Nation, and the States" under the direction of Matthew A. Crenson at Johns Hopkins University.

Kenneth A. Kersch, now at Lehigh University, won the Edward S. Corwin Award for "Frames of Progress: The Political Imagination of Rights and Liberties in the United States Supreme Court." Theodore Lowi of Cornell University served as chair of his committee. The Corwin Award goes to the best doctoral dissertation in the field of public law.

The Harold D. Lasswell Award for the best dissertation in policy studies was presented to Michael Harrington of the University of California, Los Angeles for "Trade and Social Insurance: The Development of National Unemployment Insurance in Advanced Industrial Democracies." Harrington completed his work under the direction of Jeffry A. Frieden, who moved to Harvard University after 1998, at UCLA.

Kristian S. Gleditsch of the University of Glasgow received the Helen Dwight Reid Award for the best doctoral dissertation in international relations, law, and politics. Gleditsch wrote "Peace Has Its Victories, No Less Renowned than War" under the direction of Michael D. Ward at the University of Colorado, Boulder.

The E.E. Schattschneider Award for the best doctoral dissertation in the field of American government and politics was awarded to Glen S. Krutz of Arizona State University for "Explaining Institutional Change: The Rise and Impact of Omnibus Legislating." Krutz completed his work at Texas A\&M University under the direction of Jon Bond.

Aurelian Craiutu of the University of Northern Iowa won the Leo Strauss Award for the best doctoral dissertation completed and accepted in 1999 or 2000 in the field of political philosophy for "The Difficult Apprenticeship of Liberty: Reflections on the Political Thought of the French Doctrinaires." Craiutu completed his dissertation at Princeton University under the direction of George Kateb and Alan Ryan, who has since moved to Oxford University.

The Leonard D. White Award for the best doctoral dissertation in public administration was given to William W. Newmann of Virginia Commonwealth University. His dissertation, "The Pattern of Foreign Policy Decision Making: Developing an Evolutionary Model," was completed at the University of Pittsburgh under the direction of Paul Hammond.

Awards were also given for outstanding publications. The Pi Sigma Alpha/ Franklin L. Burdette Award for the best paper presented at the 1999

Annual

Meeting went to Herbert Kitschelt of Duke University for "Accounting for Outcomes of Post-Communist Regime Change: Casual Depth or Shallowness in Rival Explanations."

The Heinz Eulau Award for the best article published in the American Political Science Review during 1999 was presented to Carles Boix of the University of Chicago. Boix's article, "Setting the Rules of the Game: The Choice of Electoral Systems in Advanced Democracies," was printed in the September issue of APSR.

The Ralph Bunche Award for the best scholarly work in political science published in 1999 that explores the phenomenon of ethnic and cultural pluralism was given to three people for two books. Steven L.

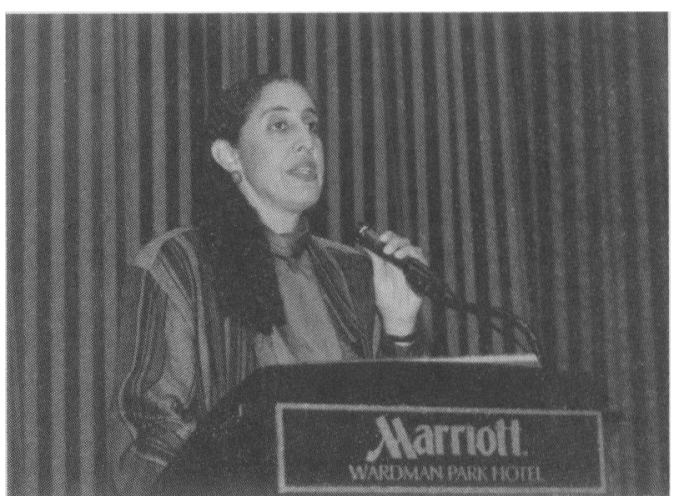

Hot Topics. The 2000 meeting included a number of special sessions featuring (from top), Lani Guinier speaking on "The Miners Canary: Rethinking Race, Representation, and Power"; a retrospective on the Clinton presidency that brought together, among others, former Speaker of the House Newt Gingrich (foreground) and Secretary of Health and Human Services Donna Shalala; and House Rules Chairman David Dreier addressing the topic of "Leadership Challenges in the Contemporary House" as part of a panel that featured a number of congressional scholars. 
David Cole of Georgetown Univesity was presented with the Gladys M. Kammerer Award for No Equal Justice: Race and Class in the American Criminal Justice System (The New Press). The Kammerer prize is give for the best book in the field of U.S. national policy.

The Victoria Schuck Award for the best book published in 1999 on women and politics went to Judith
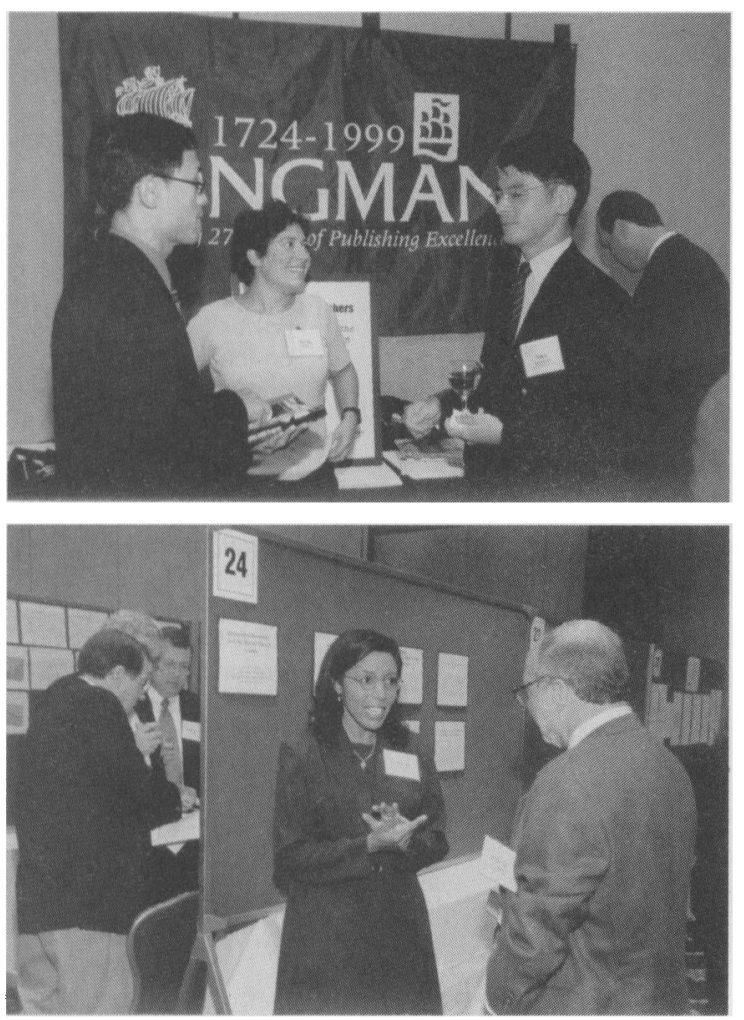

Building community. (From top) The first APSA welcome reception brought together graduate students, international participants, and first-time attendees. Poster sessions allow presenters and attendees to hold more in-depth conversations on research.

Baer of Texas A\&M University for her work, Our Lives before the Law; Constructing a Feminist Jurisprudence (Princeton University Press).

Barry O'Neill of Stanford University was awarded the Woodrow Wilson Foundation Award for Honor, Symbols, and War (University of Michigan Press). The Woodrow Wilson Foundation Award goes to the author of the best book published in 1999 on government, politics, or international affairs.

Full citations for all awards appear in the Gazette section of this issue. For details on the awards process for 2001, visit www.aspanet.org/ about/awards.

\section{Addison Wesley Longman Hosts the First Welcome and Orientation Reception at the Annual Meeting}

President Robert Keohane and Annual Meeting Program Co-Chairs Ira Katznelson and Helen Milner welcomed graduate students, international visitors, and first-time attendees to the first Annual Meeting Welcome and Orientation Reception on August 30. Addison Wesley Longman Publishing generously sponsored the event. Many Council members, 2000-01 APSA President Robert Jervis, and incoming President-Elect Robert Putnam were among those on hand to help orient the crowd to the Annual Meeting.

The Welcome and Orientation Reception was designed to introduce attendees to the intricacies of a very large meeting and to make sure that people had an opportunity to get acquainted with APSA leadership and staff. The reception drew a large crowd, presented each attendee with the opportunity to meet with other attendees and ask questions. APSA hopes to make this an annual event.

\section{Ralph Bunche Students Exhibit Work during Annual Meeting}

Eleven students from a talented class of 20 were chosen to present their work in a poster session at APSA's 2000 Annual Meeting. The students and their projects were:

Adan Balboa, St. Mary's University (TX): "Behind the Burro: Applying Dawson's Theories of Utility Heuristic and Linked Fate to Mexican Americans"

Yashica Danridge, Howard University: "The Influence of Age and Socioeconomic Status on the Support of an Independent Black Political Party"

\section{Nearly 1300 Annual Meeting Papers Now Available Online; Project Must Be Self-Sustaining by Next Year}

Papers from the 2000 Annual Meeting are now available online at http://pro.harvard.edu. The invitation to submit their papers to PROceedings: Political Research Online, the online collection of APSA Annual Meeting papers, was heeded by almost 1300 paper authors.

The paper submission site opened on July 1 and closed on September 3, the last day of the Annual Meeting. The 2000 papers, which can be searched by title or keyword, will remain online through August 2001, when the 2001 papers will be made available.

PROceedings, which is supported by a grant from The Andrew W. Mellon Foundation, is a collaborative effort of APSA and Harvard University Library under the direction of William J. Ball of The College of New Jersey. The project aims to continue Annual Meetings beyond their settings, to disseminate political science research more broadly and directly, to encourage the instructional use of recent research, and to facilitate individual and library access to the meeting papers.

PROceedings must be self-supporting by Spring of 2001, as this is the last year that PROceedings will be supported by the Mellon Foundation grant. APSA and its partners have engaged three consultants who will make recommendations to the APSA Council on the project's business plan. Current options for raising the revenue necessary to sustain the project include one or more of the following: increasing membership fees, increasing meeting registration fees, charging a paper submission fee, and/or charging a proposal submission fee. APSA is exploring the possibility of having a commercial vendor print individual copies of conference papers on demand on-site at the meeting. If feasible, such a service would be offered in lieu of the traditional panel paper room.

Take the opportunity to view the PROceedings site. If you have any questions or comments about the PROceedings project, please write to proceedings@apsanet.org. 